\title{
Effects of naloxone and diazepam on blood glucose levels in tramadol overdose using generalized estimating equation (GEE) model; (an experimental study)
}

Samaneh Nakhaee ${ }^{1}$, Khadijeh Farrokhfall1', Ebrahim Miri-Moghaddam², Masoumeh Askari', Alireza Amirabadizadeh', Mohsen Foadoddini ${ }^{2}$ and Omid Mehrpour ${ }^{1,3^{*}}$

\begin{abstract}
Background: Tramadol is a synthetic opioid and poisoning is increasing around the world day by day. Various treatments are applied for tramadol poisoning. Due to the unknown effects of tramadol poisoning and some of its treatments on blood glucose levels, this study was conducted to investigate the overdose of tramadol and its common treatments (naloxone, diazepam), and their combination on blood glucose levels in male rats.

Methods: This study was conducted in 45 male Wistar rats. The animals were randomly divided into five groups of 9. They received a $75 \mathrm{mg} / \mathrm{kg}$ dose of tramadol alone with naloxone, diazepam, and a combination of both of these two drugs. On the last day, animals' tail vein blood glucose levels (BGL) were measured using a glucometer at different times, including before the tramadol injection (baseline) and 1 hour, 3 hours, and 6 hours after wards. The rats were anesthetized and sacrificed $24 \mathrm{~h}$ after the last injection. Blood samples were then taken, and the serum obtained was used to verify the fasting glucose concentration. Data were analyzed using SPSS software at a significance level of 0.05 using a one-way analysis of variance (ANOVA) and a generalized estimating equation (GEE).

Results: According to the GEE model results, the diazepam-tramadol and naloxone-diazepam-tramadol groups showed blood glucose levels five units higher than the tramadol group $(p<0.05)$. The diazepam-tramadol group had significantly higher blood glucose levels than the naloxone-tramadol group $(p<0.05)$. The mean blood glucose levels before the intervention, 3 hours and 6 hours after the injection of tramadol did not differ between the groups, but the blood glucose levels 1 hour after the injection of tramadol in the group of naloxone-tramadol were significantly lower than in the control group $(p<0.05$ ). Blood glucose levels did not differ between the groups $24 \mathrm{~h}$ after injection of tramadol.
\end{abstract}

\footnotetext{
* Correspondence: omid.mehrpour@yahoo.com.au

'Medical Toxicology and Drug Abuse Research Center (MTDRC), Birjand University of Medical Sciences (BUMS), Birjand, Iran

${ }^{3}$ Mel and Enid Zuckerman College of Public Health, University of Arizona, Tucson, AZ, USA

Full list of author information is available at the end of the article
}

C C The Author(s). 2021 Open Access This article is licensed under a Creative Commons Attribution 4.0 International License, which permits use, sharing, adaptation, distribution and reproduction in any medium or format, as long as you give appropriate credit to the original author(s) and the source, provide a link to the Creative Commons licence, and indicate if changes were made. The images or other third party material in this article are included in the article's Creative Commons licence, unless indicated otherwise in a credit line to the material. If material is not included in the article's Creative Commons licence and your intended use is not permitted by statutory regulation or exceeds the permitted use, you will need to obtain permission directly from the copyright holder. To view a copy of this licence, visit http://creativecommons.org/licenses/by/4.0/ The Creative Commons Public Domain Dedication waiver (http://creativecommons.org/publicdomain/zero/1.0/) applies to the data made available in this article, unless otherwise stated in a credit line to the data. 
Conclusion: The results of the present study showed tramadol overdose does not affect blood glucose levels. The diazepam-tramadol combination and the diazepam-naloxone-tramadol combination caused an increase in blood glucose levels.

Keywords: Tramadol, Diazepam, Naloxone, Blood glucose, Overdose

\section{Background}

Tramadol is widely used throughout the world. This has led to an increase in the number of cases of poisoning, side effects and deaths [1]. Several cases of toxicity and abuse caused by this drug have been reported in the medical literature $[2,3]$. Tramadol is an effective pharmaceutical drug for moderate to severe pain relief that affects the transmission of pain impulses through the $\mu$-opioid receptor and inhibits norepinephrine and serotonin reuptake [4]. The most important side effects of tramadol poisoning include cognitive impairment, agitation, respiratory depression, seizures, respiratory distress, serotonin syndrome, kidney failure, and rhabdomyolysis [5]. Tramadol overdose generally leads to self-limiting, generalized, tonic-clonic seizure, most frequently occurring during $4-6 \mathrm{~h}$ after ingestion [6]. Seizure is more common in tramadol poisoning than with other opioids. Although the exact underlying mechanism of tramadolinduced seizure activity is not clarified yet, it has been suggested the seizurogenic effect of tramadol is possibly mediated via decreased serotonin reuptake and inhibitory effects on $\gamma$-aminobutyric acid (GABA) pathways [7]. Tramadol overdose-induced blood glucose changes is another potential side effect that has received insufficient attention. These changes may be among the predisposing factors for seizures in patients presenting with tramadol overdose [8]. Altered blood glucose has been associated with changes in hepatic gluconeogenesis and peripheral glucose uptake [9]. Serial blood glucose monitoring has been instructed to detect and manage hypoglycemia and hyperglycemia in tramadol overdose [8]. A recent systematic review disclosed that hypoglycemia is more likely to occur than hyperglycemia after tramadol administration with therapeutic use and overdose. Also, all studies on tramadol use in diabetes documented hypoglycemia [1].

In tramadol poisoning cases several treatments are applied, however, there are some debates and challenges regarding the exact indications for using these treatments. The effects of these treatments have been investigated in tramadol-induced seizures [10-13], but their effects on blood glucose levels are less well studied. Naloxone can be used as an opioid antagonist to prevent respiratory depression in tramadol overdose cases [10] Benzodiazepines are other drugs used in seizures caused by tramadol poisoning [6]. Several studies on these two drugs' effects on glucose metabolism have reported conflicting results [14-19]. To our knowledge, no studies have examined their effects on BGL when used to treat tramadol poisoning. This study was conducted to investigate tramadol, naloxone, diazepam, and their combination in male rats' blood glucose.

\section{Methods}

This study was conducted in 45 male Wistar rats (body weight 200-250 g, 12 weeks) under standard laboratory conditions (constant room temperature $\left(22 \pm 2{ }^{\circ} \mathrm{C}\right.$ ), light / dark periods of $12 \mathrm{~h}$, and free access to food and water). The rats were purchased from the animal experimental center of Birjand University of Medical Sciences (Birjand, Iran).

The Institutional Animal Ethics Committee approved all animal experiments by Birjand University of medical sciences (Birjand, Iran) (code: IR.BUMS.REC.1397.194). This study was conducted in accordance with international and institutional guidelines for the care and use of animals. The ARRIVE (Animal Research: Reporting of in Vivo Experiments) guidelines for the standard care and animals' use were followed.

Naloxone, diazepam, and pentobarbital were obtained from Sigma-Aldrich and tramadol from Temad (Iran, Karaj). Diazepam and naloxone were dissolved in DMSO and tramadol in normal saline. The DMSO concentration for this study was $2 \%$. The injection volume was 1 $\mathrm{ml}$ per $\mathrm{kg}$ of body weight. DMSO was prescribed in an inert range for behavioral [20] and experimental [21] animal studies.

Healthy animals with typical behavior and activity from the same species, genders, weighing 200 to $250 \mathrm{~g}$, and ages of 12 weeks were included. Rats used previously in other experiments were not included. Exclusion criteria were considered death during experiments and aberrant behavior. After 1 week of adaptation to laboratory conditions, the animals were randomly divided into five groups, to include nine animals in each group: the control group, the tramadol group, the naloxone-tramadol group, the diazepam-tramadol group, and finally the naloxone-diazepam-tramadol group. The calculation of sample size is based on the "resource equation approach" design for animal studies using the formula of $\mathrm{N}=(10 / k+1) \times k$, where $N=$ total number of subjects, $k=$ number of groups [22].

- The control group (the first group) received intraperitoneally (IP) over 14 days, an injection of $0.9 \%$ normal saline. 
- The tramadol group (the second group) received an intraperitoneal injection of $25 \mathrm{mg} / \mathrm{kg}$ of tramadol for 13 days. Subsequently, on day 14, they received an intraperitoneal injection, $75 \mathrm{mg} / \mathrm{kg}$ of tramadol.

- The naloxone group (the third group) also received an intraperitoneal injection of $25 \mathrm{mg} / \mathrm{kg}$ of tramadol for 13 days. Subsequently, on day 14, they were administered $75 \mathrm{mg} / \mathrm{kg}$ of tramadol by acute intraperitoneal injection, which was accompanied by naloxone $(2 \mathrm{mg} / \mathrm{kg})$ intravenously $15 \mathrm{~min}$ after the injection of tramadol. After this, they received naloxone $(4 \mathrm{mg} / \mathrm{kg})$ for up to $6 \mathrm{~h}$ as an hourly injection [23].

- The diazepam group (the fourth group) for 13 days received $25 \mathrm{mg} / \mathrm{kg}$ of tramadol intraperitoneally. Subsequently, on day 14 , they were administered tramadol, also intraperitoneally, $75 \mathrm{mg} / \mathrm{kg}$ of acute dose. Then, $15 \mathrm{~min}$ after the tramadol injection, they were administered $1.77 \mathrm{mg} / \mathrm{kg}$ of diazepam intraperitoneally.

- The naloxone-diazepam group (fifth group) received $25 \mathrm{mg} / \mathrm{kg}$ of tramadol intraperitoneally over a period of 13 days. On day 14, they were injected intraperitoneally with tramadol at an acute dose of $75 \mathrm{mg} / \mathrm{kg}$, an injection of $1.77 \mathrm{mg} / \mathrm{kg}$ of intraperitoneal diazepam, and intravenous naloxone at a dose of $2 \mathrm{mg} / \mathrm{kg}$. Finally, for up to $6 \mathrm{~h}$, they received an injection of 4 $\mathrm{mg} / \mathrm{kg}$ of naloxone every hour.

On the last day, the rat tail vein blood glucose levels were measured using a glucometer by making a $2 \mathrm{~mm}$ transverse incision at the end of the animal's tail. On the fourteenth day, blood glucose was measured in all groups at different times, including before the injection of tramadol (baseline) and 1 hour, 3 hours, and 6 hours after tramadol injection. The rats were also clinically monitored for $6 \mathrm{~h}$ on the final experimental day, and the number of seizures in different groups were recorded using a video recorder. The toxicity of tramadol and its dose selection were based on the onset of typical tramadol overdose features in the rats; our model exhibited tramadol-induced seizures and decreased level of consciousness similar to that reported in humans [24-26]. The animal model for tramadol overdose was based on how patients who use tramadol chronically may intentionally or accidentally overdose. Rats were anesthetized and sacrificed by intraperitoneal administration of $60 \mathrm{mg} / \mathrm{kg}$ of pentobarbital $24 \mathrm{~h}$ after the last injection (fasting for 12 to $14 \mathrm{~h}$ ). Blood samples were then taken. Serum was obtained by centrifugation of the samples and stored until the parameters were measured. The serum achieved was used to evaluate the fasting glucose concentration and creatinine levels. The experimenter was aware of the rat group, but a researcher blinded to the group allocation carried out statistical analysis and outcome assessment.

After collection, the data were entered into the SPSS software (version. 16). Using the Shapiro Wilk test, the hypothesis of normality of the quantitative variables was examined. One-way analysis of variance (ANOVA) and Bonferroni's post hoc test was used to compare means in various groups. The generalized estimation equation (GEE) model was used to analyze the longitudinal variables of blood glucose at different times. The longitudinal variable was entered as a dependent variable in the GEE model and the group as an explanatory variable. The level of significance was considered less than 0.05 .

\section{Results}

One death occurred in the naloxone-diazepam-tramadol group during the study. Before and after the study, the rats' mean weight did not differ between the groups $(p>$ 0.05 ). The number of seizures for each animal was counted, and then the average of all seizures occurring in each group was calculated and compared $\left(\chi^{2}=13.2\right.$, $p=0.01$ ). The number of seizures in all experimental groups was significantly higher than the control group. The naloxone-diazepam significantly decreased the incidence of seizures compared to the tramadol group $(P<$ 0.05) (Figs. 1 and 2).

This study showed that a low dose of tramadol administration for thirteen days did not affect glucose levels. The ANOVA test results showed the mean blood

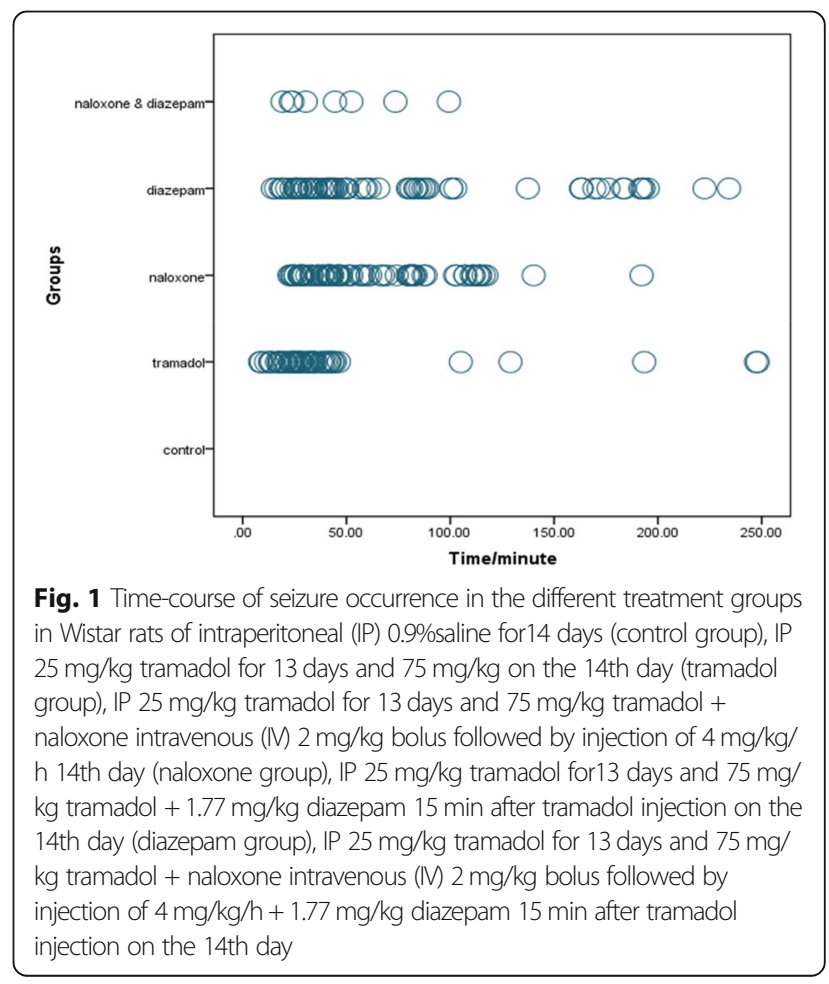




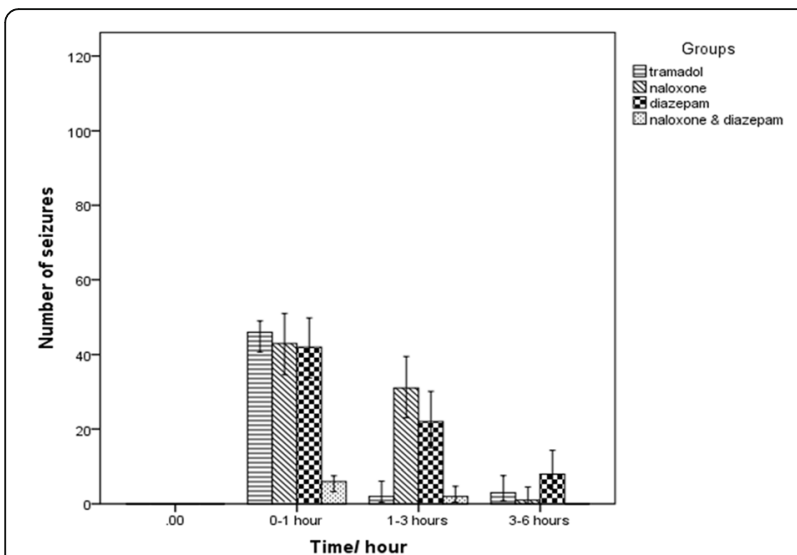

Fig. 2 The number of seizures occurring during $6 \mathrm{~h}$ in the different groups in Wistar rats of intraperitoneal (IP) $0.9 \%$ saline for 14 days (control group), IP $25 \mathrm{mg} / \mathrm{kg}$ tramadol for 13 days and $75 \mathrm{mg} / \mathrm{kg}$ on the 14th day (tramadol group), IP $25 \mathrm{mg} / \mathrm{kg}$ tramadol for 13 days and $75 \mathrm{mg} / \mathrm{kg}$ tramadol + naloxone intravenous (IV) $2 \mathrm{mg} / \mathrm{kg}$ bolus followed by injection of $4 \mathrm{mg} / \mathrm{kg} / \mathrm{h}$ 14th day (naloxone group), IP 25 $\mathrm{mg} / \mathrm{kg}$ tramadol for 13 days and $75 \mathrm{mg} / \mathrm{kg}$ tramadol $+1.77 \mathrm{mg} / \mathrm{kg}$ diazepam 15 min after tramadol injection on the 14th day (diazepam group), IP $25 \mathrm{mg} / \mathrm{kg}$ tramadol for 13 days and $75 \mathrm{mg} / \mathrm{kg}$ tramadol + naloxone intravenous (IV) $2 \mathrm{mg} / \mathrm{kg}$ bolus followed by injection of $4 \mathrm{mg} / \mathrm{kg} / \mathrm{h}+1.77 \mathrm{mg} / \mathrm{kg}$ diazepam $15 \mathrm{~min}$ after tramadol injection on the 14th day

glucose levels before the intervention $(\mathrm{F}=0.25, p=0.9)$, 3 hours $(\mathrm{F}=0.31, p=0.8)$, and 6 hours $(\mathrm{F}=1.17, p=0.3)$ after the injection of tramadol did not differ between the groups. Still, 1 hour after the tramadol injection, there was a significant difference between groups $(\mathrm{F}=4.65$, $p=0.005)$, so that the glucose level in the naloxonetramadol group was significantly lower than in the control group based on the Bonferroni's post hoc test ( $p=$ $0.002)$. There was no significant difference between the other groups $(p>0.05)$ (Fig. 3).

According to this study, the mean blood glucose levels $24 \mathrm{~h}$ after tramadol injection did not differ between the groups ( $\mathrm{F}=2.43, p=0.07$ ) (Fig. 4).

The diazepam-tramadol and naloxone-diazepamtramadol groups showed blood glucose levels five units higher than the tramadol group based on the GEE model results $(p=0.01)$. Furthermore, the diazepam-tramadol group had significantly higher blood glucose levels than the naloxone-tramadol group $(\mathrm{B}=7.04, p=0.004)$. The other groups did not show significant effects on blood glucose compared to each other $(p>0.05)$ (Table 1).

All study groups, except the control group showed a similar pattern of blood glucose changes at different times such that 1 hour after tramadol injection they all showed a decrease in blood glucose levels and these values returned nearly close to baseline levels 3 hours after injection (Fig. 5). One-way analysis of variance showed that mean creatinine levels were significantly different between groups $(\mathrm{F}=4.5, \quad p=0.007)$.

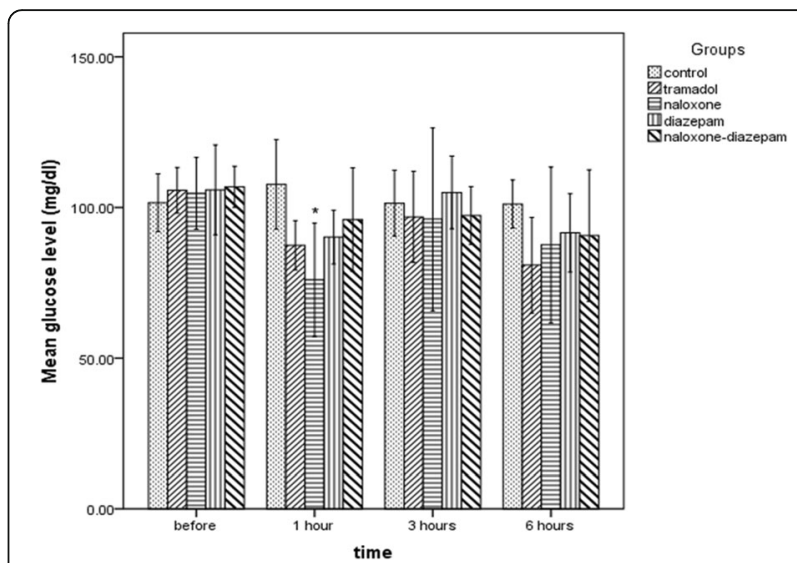

Fig. 3 Comparison of blood glucose levels in different times in Wistar rats of intraperitoneal (IP) 0.9\%saline for14 days (control group), IP $25 \mathrm{mg} / \mathrm{kg}$ tramadol for 13 days and $75 \mathrm{mg} / \mathrm{kg}$ on the 14th day (tramadol group), IP $25 \mathrm{mg} / \mathrm{kg}$ tramadol for 13 days and $75 \mathrm{mg} / \mathrm{kg}$ tramadol + naloxone intravenous (IV) 2 $\mathrm{mg} / \mathrm{kg}$ bolus followed by injection of $4 \mathrm{mg} / \mathrm{kg} / \mathrm{h}$ 14th day (naloxone group), IP $25 \mathrm{mg} / \mathrm{kg}$ tramadol for 13 days and $75 \mathrm{mg} / \mathrm{kg}$ tramadol $+1.77 \mathrm{mg} / \mathrm{kg}$ diazepam 15 min after tramadol injection on the 14th day (diazepam group), IP $25 \mathrm{mg} / \mathrm{kg}$ tramadol for 13 days and $75 \mathrm{mg} / \mathrm{kg}$ tramadol + naloxone intravenous (IM) $2 \mathrm{mg} / \mathrm{kg}$ bolus followed by injection of $4 \mathrm{mg} / \mathrm{kg} / \mathrm{h}+1.77 \mathrm{mg} /$ $\mathrm{kg}$ diazepam $15 \mathrm{~min}$ after tramadol injection on the 14th day. Data are the mean \pm SD. ${ }^{*} p<0.05$ compared to control group

Bonferroni's post hoc test showed Tramadol had no significant effects on creatinine levels. Still, the naloxonediazepam-tramadol significantly increased the mean creatinine levels compared to control $(0.52, \pm 0.1$ vs. $0.35 \pm$

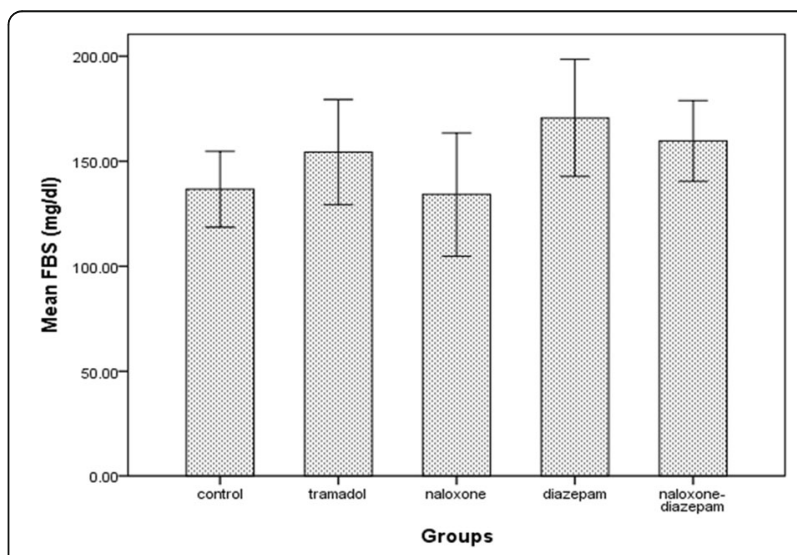

Fig. 4 Comparison of fasting blood glucose levels in different groups after $24 \mathrm{~h}$ in Wistar rats of intraperitoneal (IP) 0.9\%saline for 14 days (control group), IP $25 \mathrm{mg} / \mathrm{kg}$ tramadol for 13 days and $75 \mathrm{mg} /$ $\mathrm{kg}$ on the 14th day (tramadol group), IP $25 \mathrm{mg} / \mathrm{kg}$ tramadol for 13 days and $75 \mathrm{mg} / \mathrm{kg}$ tramadol + naloxone intravenous (IV) $2 \mathrm{mg} / \mathrm{kg}$ bolus followed by injection of $4 \mathrm{mg} / \mathrm{kg} / \mathrm{h}$ 14th day (naloxone group), IP $25 \mathrm{mg} / \mathrm{kg}$ tramadol for 13 days and $75 \mathrm{mg} / \mathrm{kg}$ tramadol + $1.77 \mathrm{mg} /$ $\mathrm{kg}$ diazepam $15 \mathrm{~min}$ after tramadol injection on the 14th day (diazepam group), IP $25 \mathrm{mg} / \mathrm{kg}$ tramadol for 13 days and $75 \mathrm{mg} / \mathrm{kg}$ tramadol + naloxone intravenous (IV) $2 \mathrm{mg} / \mathrm{kg}$ bolus followed by injection of $4 \mathrm{mg} / \mathrm{kg} / \mathrm{h}+1.77 \mathrm{mg} / \mathrm{kg}$ diazepam $15 \mathrm{~min}$ after tramadol injection on the 14th day. Data are the mean \pm SD 
Table 1 Comparison of glucose levels in the different groups based on the GEE model

\begin{tabular}{lllll}
\hline & B & SE & Wald & p-value \\
\hline Tramadol vs Control & -10.25 & 5.24 & 3.81 & 3.38 \\
Naloxone-tramadol vs Control & -11.86 & 6.45 & 0.05 & 0.07 \\
Diazepam-tramadol vs Control & -4.82 & 4.60 & 3.09 & 0.29 \\
Naloxone-Diazepam-tramadol vs Control & -5.15 & 3.37 & 0.25 & 0.13 \\
Naloxone-tramadol vs Tramadol & -1.61 & 2.10 & 6.68 & 0.62 \\
Diazepam-tramadol vs Tramadol & 5.43 & 2.09 & 5.91 & 0.01 \\
Naloxone-Diazepam-tramadol vs Tramadol & 5.09 & 2.47 & 3.10 & 0.01 \\
Diazepam-tramadol vs Naloxone-tramadol & 7.04 & 3.89 & 2.97 & 0.004 \\
Naloxone-Diazepam-tramadol vs Naloxone-tramadol & 6.71 & 2.40 & 0.02 & 0.08 \\
Naloxone-Diazepam-tramadol vs Diazepam-tramadol & -0.36 & &
\end{tabular}

$0.04, p=0.01)$ and tramadol $(0.52, \pm 0.1$ vs. $0.36 \pm 0.05$, $p=0.02)$ groups.

\section{Discussion}

This study showed that tramadol overdose does not affect blood glucose levels although its changes are aimed at lowering blood glucose. Conflicting results have been reported in several studies. Some studies have reported hypoglycemia in tramadol poisoning [5, 8, 27-36] and others have reported elevated blood glucose levels in these individuals $[31,37,38]$. Consistent with our results, several studies have shown normal blood glucose levels in people with tramadol poisoning $[4,8,31,34$, $36,39,40]$.

The different results in different studies can be attributed to differences in the samples studied, different doses of tramadol, different measurement times of BGL, and various methods of administration. The proposed

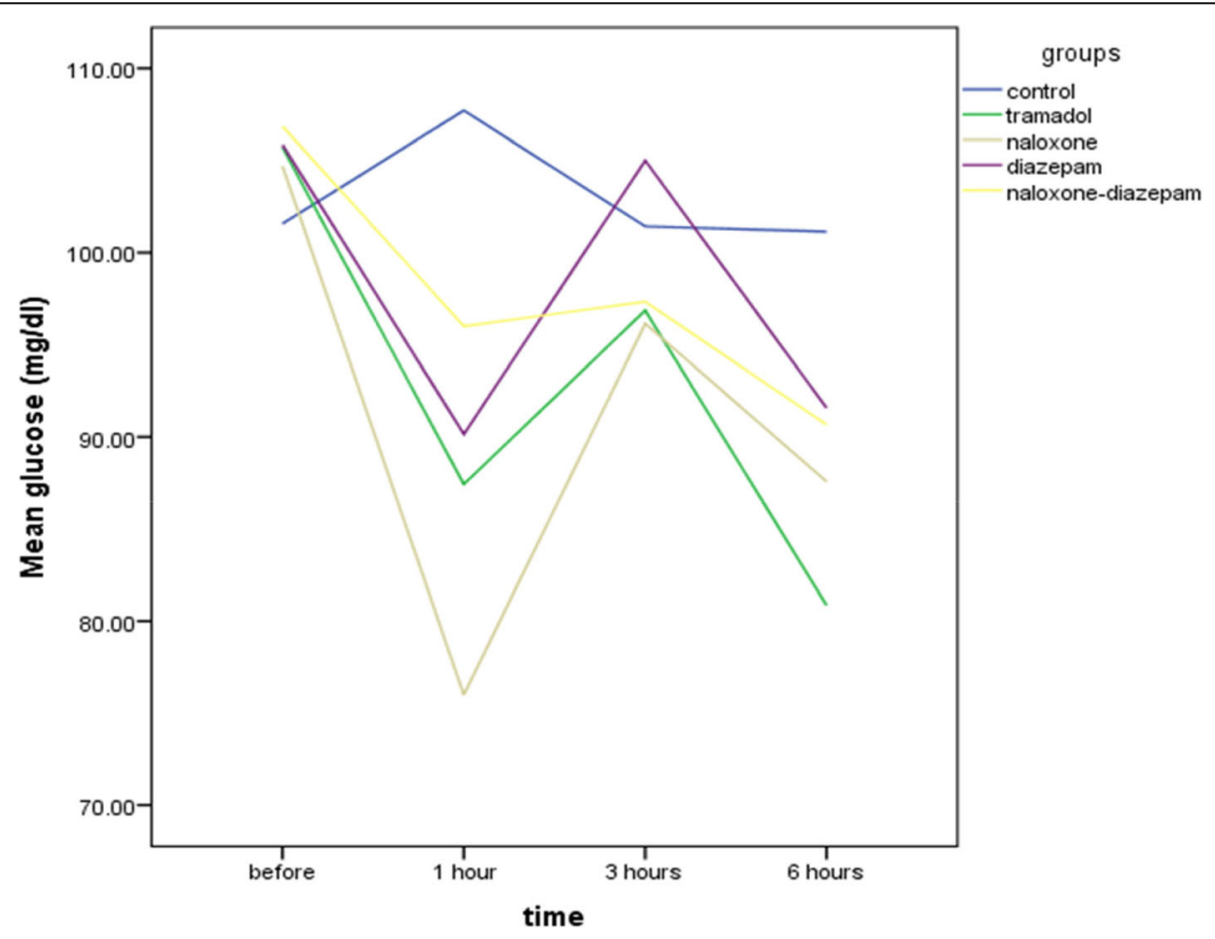

Fig. 5 Time-course of average glucose levels in the different treatment groups in Wistar rats of intraperitoneal (IP) 0.9\%saline for 14 days (control group), IP $25 \mathrm{mg} / \mathrm{kg}$ tramadol for 13 days and $75 \mathrm{mg} / \mathrm{kg}$ on the 14th day (tramadol group), IP $25 \mathrm{mg} / \mathrm{kg}$ tramadol for 13 days and $75 \mathrm{mg} / \mathrm{kg}$ tramadol + naloxone intravenous (IV) $2 \mathrm{mg} / \mathrm{kg}$ bolus followed by injection of $4 \mathrm{mg} / \mathrm{kg} / \mathrm{h}$ 14th day (naloxone group), IP $25 \mathrm{mg} / \mathrm{kg}$ tramadol for 13 days and $75 \mathrm{mg} / \mathrm{kg}$ tramadol $+1.77 \mathrm{mg} / \mathrm{kg}$ diazepam $15 \mathrm{~min}$ after tramadol injection on the 14th day (diazepam group), IP $25 \mathrm{mg} / \mathrm{kg}$ tramadol for 13 days and $75 \mathrm{mg} / \mathrm{kg}$ tramadol + naloxone intravenous (IV) $2 \mathrm{mg} / \mathrm{kg}$ bolus followed by injection of $4 \mathrm{mg} / \mathrm{kg} / \mathrm{h}+1.77 \mathrm{mg} / \mathrm{kg}$ diazepam $15 \mathrm{~min}$ after tramadol injection on the 14th day 
mechanism for tramadol's hypoglycemic effects is the activation of opioid receptors by tramadol, resulting in glucose utilization in peripheral tissues [41].

Previous reports indicate the opioid receptor is the main target involved in tramadol-induced hypoglycemia [42]. Some studies also showed serotonin could increase insulin levels, release beta-endorphins, and ultimately stimulate muscle glucose utilization [43, 44].

Catecholamines have been shown to directly suppress insulin secretion from the pancreas, causing glycogenolysis in the liver by stimulating the $\alpha$-adrenergic receptor and ultimately causing hyperglycemia $[45,46]$. Some studies showed a hyperglycemic effect of tramadol. For example, Kara et al. (2013) attributed the induction of tramadol-induced hyperglycemia to $\alpha 2$ adrenergic receptors' activity, suggesting that monoamine pathways affect the analgesic properties of tramadol and may be involved in the development of druginduced hyperglycemia [47]. Another result of this study was the increasing effect of diazepam-tramadol and naloxonediazepam-tramadol on BGL. Diazepam is widely used as a sedative and as an anticonvulsant. According to some reports, the benzodiazepine receptor mediates its action by increasing synaptic GABA inhibition [48]. According to some reports, it prevents various stress-induced changes such as activation of the HPA axis [49]. Dexit et al. prescribed diazepam $(0.6 \mathrm{mg} / \mathrm{kg} /$ day $)$ to rabbits for 1 month and reported no effect on blood glucose levels [50].

In contrast, some studies have reported that diazepam increases blood glucose in humans and animals. For example, the results of a study in mice showed that administration of diazepam $(13.3 \mathrm{mg} / \mathrm{kg})$ resulted in an increase in blood glucose levels at different times after injection [15]. Another study in rabbits showed that diazepam $(2 \mathrm{mg} / \mathrm{kg} / \mathrm{iv})$ could increase blood glucose levels [51].

Furthermore, another study in rats showed that diazepam could increase blood glucose levels in a dosedependent manner [52]. Their research suggested that diazepam effects on peripheral glucose were the possible cause of benzodiazepine-related hyperglycemia [52]. In an experimental model, the $2 \alpha$-adrenergic receptor antagonist could prevent diazepam-induced hyperglycemia. The results of this study suggested diazepam-induced hyperglycemia may be associated with adrenaline release from the adrenal gland [48].

The GABA-A receptor subunit expression has also been reported in the pancreas [53] and chromaffin cells of the adrenal medulla [54]. GABA can regulate the endocrine function of $\beta$ cells through direct or indirect activation [55].

It is hard to explain the glycemic changes of diazepam at an animal stage of examination, and the results should be interpreted with caution at this stage.

The effects of diazepam also need to be interpreted in the context of tramadol poisoning due to drug interactions. The racial and dose-dependent characteristics of glucose homeostasis must be considered when interpreting the results of various studies. And we propose to investigate these treatments in several doses. Different single-dose therapies were used in tramadol overdose in this study. Additionally, future studies may consider providing a dose-response curve and other factors related to blood glucose homeostasis. Our study has limitations, including the fact that tramadol concentrations and its metabolites (M1, M2, and M5) were not measured. Also, in this study, vein blood glucose levels (BGL) were measured using a glucometer at different times. It may be insufficient for a complete and comprehensive elucidation of a scientific conclusion. It would be more beneficial if the effect of tramadol overdose on glucose infusion test (GIT) and more kidney function tests are considered in future studies.

The generalization of animals' findings to humans should be performed cautiously due to this study's empirical nature. Assume these treatments' effects on blood glucose levels and glucose homeostasis in human tramadol overdose, the hyperglycemic effects of diazepam, and the hypoglycemic effects of naloxone in the early hours must be considered, especially for patients with diabetes.

\section{Conclusion}

Our study results showed a low dose of tramadol administration; typically, thirteen days did not affect glucose levels. Tramadol overdose had minimal effects on blood glucose levels. Naloxone administration can also decrease blood glucose levels in the first hours after tramadol overdose, diazepam -tramadol combination and diazepam-naloxone- tramadol combination may increase blood glucose levels in the event of a tramadol overdose.

\section{Abbreviations}

GEE: Generalized estimating equation; GABA: $\gamma$-Aminobutyric acid; DMSO: Dimethyl sulfoxide; IP: Intraperitoneal; BGL: Blood glucose levels; ANOVA: One-way analysis of variance

\section{Acknowledgements}

Not applicable.

\section{Authors' contributions}

$\mathrm{SN}, \mathrm{KF}, \mathrm{EM}, \mathrm{MF}, \mathrm{OM}$ contributed to conception, design, and preparation of the manuscript. SN, KF, MA, AA, OM contributed to conducting experiments, acquisition, analysis, and interpretation. SN, KF, EM, MF, MA, AA, and OM made substantial contributions in drafting the manuscript and revising it critically for important intellectual content. All authors have read and approved the final version of manuscript.

\section{Funding}

This study was supported by grants from the research council of Birjand University of Medical Sciences (Grant number: 455668), Birjand, Iran, and from the Iran National Science Foundation (INSF) (Grant number: 97012231). The funding body had no role in the design of the study and collection, analysis, and interpretation of data and in writing the manuscript. 


\section{Availability of data and materials}

The datasets are available from the corresponding author on formal and logic request.

\section{Declarations}

\section{Ethics approval and consent to participate}

All animal experiments were approved by Institutional Animal Ethics Committee of Birjand University of medical sciences (Birjand, Iran) (code: IR.BUMS.REC.1397.194). This study was conducted in accordance with international and institutional guidelines for the care and use of animals. The ARRIVE (Animal Research: Reporting of in Vivo Experiments) guidelines for the standard care and use of animals were followed.

\section{Consent for publication}

Not applicable.

\section{Competing interests}

The authors take full responsibility for the writing and content of this article and confirm that there are no conflicts of interests associated with this academic publication.

\section{Author details}

${ }^{1}$ Medical Toxicology and Drug Abuse Research Center (MTDRC), Birjand University of Medical Sciences (BUMS), Birjand, Iran. ${ }^{2}$ Cardiovascular Diseases Research Center, Birjand University of Medical Sciences, Birjand, Iran. ${ }^{3} \mathrm{Mel}$ and Enid Zuckerman College of Public Health, University of Arizona, Tucson, $A Z$, USA.

Received: 4 January 2021 Accepted: 24 August 2021

\section{Published online: 06 September 2021}

\section{References}

1. Nakhaee S, Brent J, Hoyte C, Farrokhfall K, Shirazi FM, Askari M, et al. The effect of tramadol on blood glucose concentrations: a systematic review. Expert Rev Clin Pharmacol. 2020;13(5):531-43.

2. Doostmohammadi M, Rahimi HR. ADME and toxicity considerations for tramadol: from basic research to clinical implications. Expert Opin Drug Metab Toxicol. 2020;16(7):627-40.

3. Nakhaee S, Amirabadizadeh A, Brent J, Miri-Moghaddam E, Foadoddini M, Farrokhfall $\mathrm{K}$, et al. Tramadol and the occurrence of seizures: a systematic review and meta-analysis. Crit Rev Toxicol. 2019;49(8):710-23.

4. Ghazimirsaeid SA, Khakzad M, Dinpanah H, Amani N, Rahimi M, Manuchehri AA. Tramadol, seizure caused by an overdose and acute renal failure: a case report. World Appl Sci J. 2014;32(7):1204-8.

5. Majidi M, Nekouei Fard S. Refractory seizures in tramadol poisoning: a case report. Iran J Toxicol. 2014;8(26):1157-9.

6. Lagard C, Chevillard L, Malissin I, Risède P, Callebert J, Labat L, et al. Mechanisms of tramadol-related neurotoxicity in the rat: does diazepam/ tramadol combination play a worsening role in overdose? Toxicol Appl Pharmacol. 2016;310:108-19.

7. Valian N, Sorayya M, Asadi S, Sherafati F, Ershad A, Savaheli S, et al. Preconditioning by ultra-low dose of tramadol reduces the severity of tramadol-induced seizure: contribution of glutamate receptors. Biomed Pharmacother. 2021;133:111031.

8. Nasouhi S, Talaie H, Pajoumand A, Aghapour S, Rahimi M, Khorasani AG, et al. Hypo and hyperglycemia among tramadol overdose patients in Loghman hakim hospital, Tehran, Iran. Pak J Pharm Sci. 2015;28(6):1959-63.

9. Nelson LS, Juurlink DN. Tramadol and hypoglycemia: one more thing to worry about. JAMA Intern Med. 2015;175(2):194-5.

10. Eizadi-Mood N, Ozcan D, Sabzghabaee AM, Mirmoghtadaee P, Hedaiaty M. Does naloxone prevent seizure in tramadol intoxicated patients? Int J Prev Med. 2014;5(3):302.

11. Farzaneh E, Mostafazadeh B, Mehrpour O. Seizurogenic effects of low-dose naloxone in tramadol overdose. Iran J Pharmacol Ther. 2012;11(1):6-0.

12. Saidi H, Ghadiri M, Abbasi S, Ahmadi S-F. Efficacy and safety of naloxone in the management of postseizure complaints of tramadol intoxicated patients: a self-controlled study. Emerg Med J. 2010;27(12):928-30.

13. Shadnia S, Brent J, Mousavi-Fatemi K, Hafezi P, Soltaninejad K. Recurrent seizures in tramadol intoxication: implications for therapy based on 100 patients. Basic Clin Pharmacol Toxicol. 2012;111(2):133-6.
14. Ipp E, Garberoglio C, Richter H, Moossa AR, Rubenstein AH. Naloxone decreases centrally induced hyperglycemia in dogs: evidence for an opioid role in glucose homeostasis. Diabetes. 1984;33(7):619-21.

15. Mohammed A, Al-Hozab A, Alshaheen T. Effects of diazepam and xylazine on changes of blood oxygen and glucose levels in mice. Adv Anim Vet Sci. 2018;6(3):121-7.

16. Morley JE, Baranetsky NG, Wingert TD, Carlson HE, Hershman JM, Melmed S, et al. Endocrine effects of naloxone-induced opiate receptor blockade. J Clin Endocrinol Metab. 1980;50(2):251-7.

17. Schaira VRL, Ranali J, Saad MJA, De Oliveira PC, Ambrosano GMB, Volpato MC. Influence of diazepam on blood glucose levels in nondiabetic and noninsulin-dependent diabetic subjects under dental treatment with local anesthesia. Anesth Prog. 2004;51(1):14.

18. Syvälahti E, Kanto J. Serum growth hormone, serum immunoreactive insulin and blood glucose response to oral and intravenous diazepam in man. Int J Clin Pharmacol Biopharm. 1975;12(1-2):74-82.

19. Theodore WH, Leiderman D, Gaillard W, Khan I, Reeves P, Lloyd-Hontz K. The effect of naloxone on cerebral blood flow and glucose metabolism in patients with complex partial seizures. Epilepsy Res. 1993;16(1):51-4.

20. Cavas M, Beltrán D, Navarro JF. Behavioural effects of dimethyl sulfoxide (DMSO): changes in sleep architecture in rats. Toxicol Lett. 2005;157(3):221-32.

21. Malfará WR. Souza AMd, Queiroz RHC: ranitidine treatment inducing methemoglobinemia in male Wistar rats. Revista Brasileira de Ciências Farmacêuticas. 2005;41(2):247-52.

22. Arifin WN, Zahiruddin WM. Sample size calculation in animal studies using resource equation approach. Malaysian J Med Sci MJMS. 2017;24(5):101.

23. Lagard C, Malissin I, Indja W, Risède P, Chevillard L, Mégarbane B. Is naloxone the best antidote to reverse tramadol-induced neuro-respiratory toxicity in overdose? An experimental investigation in the rat. Clin Toxicol. 2017;56(8):737-43.

24. Marquardt KA, Alsop JA, Albertson TE. Tramadol exposures reported to statewide poison control system. Ann Pharmacother. 2005;39(6): 1039-44.

25. Shadnia S, Soltaninejad K, Heydari K, Sasanian G, Abdollahi M. Tramadol intoxication: a review of 114 cases. Hum Exp Toxicol. 2008;27(3):201-5.

26. Hassanian-Moghaddam H, Farajidana H, Sarjami S, Owliaey H. Tramadolinduced apnea. Am J Emerg Med. 2013;31(1):26-31.

27. Aliyu I, Kyari F, Ibrahim Z. Hypoglycemia in a child with tramadol poisoning. Saudi J Med Med Sci. 2016:4(1):35-7.

28. De Decker K, Cordonnier J, Jacobs W, Coucke V, Schepens P, Jorens PG. Fatal intoxication due to tramadol alone: case report and review of the literature. Forensic Sci Int. 2008;175(1):79-82.

29. El-Hussuna A, Arnesen RB, Rosenberg J. Tramadol poisoning with hyperamylasemia. BMJ Case Rep. 2010;2010:bcr0320102821.

30. Elkalioubie A, Allorge D, Robriquet L, Wiart J-F, Garat A, Broly F, et al. Nearfatal tramadol cardiotoxicity in a CYP2D6 ultrarapid metabolizer. Eur J Clin Pharmacol. 2011;67(8):855-8.

31. Fouad S, Hassan N, Nassief N, El-Halawany F, Hussien R. Critical score as a predictor for progression of tramadol intoxication. J Clin Toxicol. 2015; 5(249):2161-0495.1000249.

32. Granauro P, Di Comite V, Lippi G, Marzi U, Cervellin G. Severe acute lactic acidosis and hypoglycemia due to isolate tramadol poisoning. Emerg Care J. 2016;12(2):40-1.

33. Ly BT, Thornton SL, Buono C, Stone JA, Wu AH. False-positive urine phencyclidine immunoassay screen result caused by interference by tramadol and its metabolites. Ann Emerg Med. 2012;59(6):545-7.

34. Moulis F, Rousseau V, Abadie D, Masmoudi K, Micallef J, Vigier C, et al. Serious adverse drug reactions with tramadol reported to the French pharmacovigilance database between 2011 and 2015. Therapie. 2017;72(6):615-24.

35. Mugunthan N, Davoren P. Danger of hypoglycemia due to acute tramadol poisoning. Endocr Pract. 2012;18(6):e151-2.

36. Othong R, Srisang W. Tramadol-induced seizures in adolescents and young adults in Bangkok: clinical features and emergency management. J Med Assoc Thail. 2018;101(8):S167-75.

37. Elyazji NR, Abdel-Aziz I, Aldalou A, Shahwan O. The effects of tramadol hydrochloride administration on the hematological and biochemical profiles of domestic male rabbits. IUG J Nat Stud. 2015;21(2):51-6.

38. Wang S-Q, Li C-S, Song Y-G. Multiply organ dysfunction syndrome due to tramadol intoxication alone. Am J Emerg Med. 2009;27(7):903 e905-903. e907.

39. Nasr MA, Mahmoud SF, Mohammad MA, El-Samie A, Hesham S. A study of clinical and laboratory picture of acute tramadol toxicity in damietta governorate. Mansoura J Forensic Med Clin Toxicol. 2018;26(2):143-53. 
40. Salmi A. TRAMADOL ${ }^{\circledR}$... . Beyond its beneficial effects. J Clin Toxicol. 2016; 6(1):282

41. Cheng JT, Liu IM, Chi TC, Tzeng TF, Lu FH, Chang CJ. Plasma glucoselowering effect of tramadol in streptozotocin-induced diabetic rats. Diabetes. 2001;50(12):2815-21.

42. Grandvuillemin A, Jolimoy G, Authier F, Dautriche A, Duhoux F, Sgro C. Tramadol-induced hypoglycemia. Presse Med. 2006;35(12):1842-4.

43. Chi T-C, Ho Y-J, Chen W-P, Chi T-L, Lee S-S, Cheng J-T, et al. Serotonin enhances $\beta$-endorphin secretion to lower plasma glucose in streptozotocininduced diabetic rats. Life Sci. 2007;80(20):1832-8.

44. Yamada J, Sugimoto Y, Kimura I, Takeuchi N, Horisaka K. Serotonin-induced hypoglycemia and increased serum insulin levels in mice. Life Sci. 1989; 45(20):1931-6

45. Bole D, Simon B. Pheochromocytoma-induced hyperglycemia leading to misdiagnosis of type 1 diabetes mellitus. AACE Clin Case Rep. 2017:3(1):e83-6.

46. Porte D. A receptor mechanism for the inhibition of insulin release by epinephrine in man. J Clin Invest. 1967;46(1):86-94.

47. Kara H, Karci A, Gümüştekin M, Örmen M, Taşdöğen A, Elar Z. The effect of tramadol on blood glucose levels in rats. Open J Anesthesiol. 2013;3(01):18.

48. Yamada J, Sugimoto Y, Noma T. Involvement of adrenaline in diazepaminduced hyperglycemia in mice. Life Sci. 2000;66(13):1213-21.

49. Sugimoto Y, Yamada J, Noma T. Effects of anxiolytics, diazepam and tandospirone, on immobilization stress-induced hyperglycemia in mice. Life Sci. 1998;63(14):1221-6

50. Dixit R, Puri J, Sharma M, Jain I, Singh S, Ansari N, et al. Effect of anxiolytics on blood sugar level in rabbits; 2001.

51. Sarov M, llieva G. Diazepam impairs glucose tolerance and increases serum glucose in NZW rabbits. Comptes Rendus de l'Academie Bulgare des Sciences. 2003;56(11):11-77.

52. Salice V, Valenza F, Pizzocri M, Valenti L, Chevallard G, Umbrello M, et al. Benzodiazepines induce hyperglycemia in rats by affecting peripheral disposal of glucose. Crit Care. 2013;17(2):1-200.

53. Borboni P, Porzio O, Fusco A, Sesti G, Lauro R, Marlier L. Molecular and cellular characterization of the GABAA receptor in the rat pancreas. Mol Cell Endocrinol. 1994;103(1-2):157-63.

54. Parramón M, Oset-Gasque M, Gonzalez M, Stephenson F. Identification of GABAA receptor subunits expressed in bovine adrenal medulla. Neurosci Lett. 1994;168(1-2):243-6.

55. Brice N, Varadi A, Ashcroft S, Molnar E. Metabotropic glutamate and GABAB receptors contribute to the modulation of glucose-stimulated insulin secretion in pancreatic beta cells. Diabetologia. 2002;45(2):242-52.

\section{Publisher's Note}

Springer Nature remains neutral with regard to jurisdictional claims in published maps and institutional affiliations.

Ready to submit your research? Choose BMC and benefit from:

- fast, convenient online submission

- thorough peer review by experienced researchers in your field

- rapid publication on acceptance

- support for research data, including large and complex data types

- gold Open Access which fosters wider collaboration and increased citations

- maximum visibility for your research: over $100 \mathrm{M}$ website views per year

At $\mathrm{BMC}$, research is always in progress.

Learn more biomedcentral.com/submissions 